\title{
MODEL KEPEMIMPINAN VISIONER KEPALA SEKOLAH DALAM PELAKSANAAN KEGIATAN EKSTRAKURIKULER
}

\author{
Herni \\ Institut Agama Islam Negeri Palopo \\ E-mail: herni160620@gmail.com
}

\begin{abstract}
Abstrak
Penelitian ini bertujuan untuk mengetahui kegiatan ekstrakurikuler kompetitif, untuk memahami kepemimpinan visioner kepala sekolah yang memimpin pelaksanaan kegiatan ekstrakurikuler dan untuk mengetahui model kepemimpinan visioner kepala sekolah dalam mengembangkan pembelajaran ekstrakurikuler di SMAN 1 Palopo. Penelitian ini adalah penelitian kualitatif. Itu menggunakan manajerial, psikologis, perspektif sosiologis, pendekatan keagamaan. Instrumen yang digunakan yaitu pengumpulan data observasi, wawancara, dan dokumentasi. Analisis data penelitian ini menggunakan reduksi data, penyajian data, triangulasi, serta penarikan kesimpulan. Hasil penelitian menyimpulkan bahwa: 1) Kegiatan ekstrakurikuler di SMAN 1 Palopo terdiri dari kegiatan pramuka, kegiatan ekstrakurikuler bola basket, dan kegiatan ekstrakurikuler berbaris 2) Kepemimpinan visioner kepala sekolah yang memimpin pelaksanaan kegiatan ekstrakurikuler. di sen SMAN 1 Palopo dapat dilihat dari perspektif visi dan misi yang jelas, memiliki inovasi tinggi, keteladanan dan disiplin yang tinggi, dan kepala sekolah menjadi agen perubahan. 3) Model kepemimpinan visioner kepala sekolah dalam mengembangkan pembelajaran ekstrakurikuler kompetitif di SMA Negeri 1 Palopo yang terdiri dari Perumusan Visi, Transformasi Visi, Implementasi Visi, serta melengkapi sarana dan prasarana.
\end{abstract}

Kata Kunci: Model Kepemimpinan Visioner, Kepemimpinan Kepala Sekolah, Ekstrakurikuler

\begin{abstract}
This research aims to determine the competitive extracurricular activities, to understand the visionary leadership of the school principal who comes in leading the implementation of the extracurricular activities and to find out the visionary leadership model of school principals in developing the extracurricular learning in SMAN 1 Palopo. This research was a qualitative study. It used managerial, psychological, sociological perspective, religious approaches. The instrument used namely observation data collection, interview, and documentation. The data analysis of the research was using data reduction, presentation of data, triangulation, as well as the withdrawal of conclusion. The results of the study conclude that: 1) The extracurricular activities in a SMAN 1 Palopo consists of the scouts, extracurricular activities basketball, and marching extracurricular activities 2) The visionary leadership of the school principal who comes in leading the implementation of the extracurricular activities in sen SMAN 1 Palopo can be seen from the perspective of a clear vision and mission planning, having high innovation, high exemplary and discipline, and the school principal becomes the agent of change. 3) Visionary leadership model of school principals in developing the competitive extracurricular learning in senior high school 1 Palopo consisting of The formulation of vision, the transformation of vision, the implementation of the vision, as well as completing the facilities and infrastructure.
\end{abstract}

Keywords: Visionary Leadership Model, School Principal Leadership, Extracurricular 
40 | Herni

\section{Pendahuluan}

Menghadapi berbagai perubahan yang senantiasa melingkupi setiap saat, menghadapi berbagai karakteristik personil yang dapat mengembangkan maupun melemahkan. Hal ini menjadi alasan diperlukannya orang yang tampil mengatur, memberi pengaruh, menata, mendamaikan, memberi penyejuk dan dapat menetapkan tujuan yang tepat saat anggota tersesat atau kebingungan menetapkan arah. Disinilah perlunya kepala sekolah yang melaksanakan kepemimpinan visioner.

Kepemimpinan visioner adalah kemampuan pemimpin dalam menciptakan, merumuskan, mensosialisasikan dan mengimplementasikan pemikiran-pemikiran ideal yang berasal dari dalam dirinya atau sebagai interaksi sosial di antara anggota organisasi dan stakeholders yang diyakini sebagai cita-cita organisasi dimasa depan yang harus diraih atau diwujudkan melalui komitmen semua personil. ${ }^{1}$ Kepemimpinan visioner salah satunya ditandai oleh kemampuan pemimpin dalam membuat perencanaan yang jelas sehingga dari rumusan visinya tersebut akan tergambar sasaran yang hendak dicapai dari pengembangan lembaga yang dipimpinnya. Bahkan perencanaan kepala sekolah, yaitu suatu sikap, a way of life, suatu proses berpikir, suatu aktivitas intelektual. ${ }^{2}$ Merumuskan visi tidak dibatasi oleh kemungkinan investigasi secara ilmiah, tetapi juga merangsang citra kejiwaan, fantasi dan intuisi, memberanikan kita menjelaskan sasaran dan memperkuat keyakinan akan kemampuan kita untuk mecapai sasaran.

Kepemimpin visioner dituntut mampu merumuskan pemikiranpemikiran ideal yang berasal dari dalam dirinya atau sebagai interaksi sosial di antara anggota organisasi menjelaskan visi kepada orang lain, mampu mengungkapkan visi tidak hanya secara verbal melainkan melalui prilaku, serta mampu memperluas visi kepada konteks kepemimpinan yang berbeda. Achmad Sanusi dan Sobry Sutikno berpendapat bahwa kepemimpinan visioner adalah pola kepemimpinan yang ditujukan untuk memberi arti pada kerja dan usaha yang perlu dilakukan bersama-sama oleh para anggota organisasi dengan cara member arahan dan makna pada kerja dan usaha yang dilakukan berdasarkan visi yang jelas. ${ }^{3}$

Kepemimpinan visioner kepala sekolah SMA Negeri 1 dalam hal ini adalah kepemimpinan yang dilakukan kepala sekolah yang memfokuskan pada peningkatan kualitas pengajaran dan pembelajaran di sekolah berdasarkan dengan visi dan misi sekolah. Kepemimpinan visioner salah satunya ditandai oleh kemampuan dalam membuat perencanaan yang jelas sehingga dari rumusan visinya tersebut akan tergambar sasaran apa yang hendak dicapai dari pengembangan lembaga yang dipimpinnya, salah satunya adalah pengembangan kegiatan ekstrakurikuler siswa di sekolah.

\footnotetext{
${ }^{1}$ Tim Dosen Administrasi Pendidikan Universitas Pendidikan Indonesia, Manajemen Pendidikan, (Bandung: Alfabeta, 2009), h. 143.

${ }^{2}$ George A, Stainer, Strategic Planning, (New York: The Free Press, 2006), p. 152.

3 Achmad Sanusi dan Sobry Sutikno, Kepemimpinan Sekarang dan Masa Depan, (Bandung: Prospect, 2009), h. 67.
} 
Karekteristik kepemimpinan visioner adalah sebagai berikut: a) Berwawasan visioner (future oriented) dan mampu menyiasati masa depan; b)Pemikir dan perencara yang strategis; c) Inovatif dan berani mengambil risiko; d) Imajnatif; e) Optimis dan antusias; f) Pemberdayaan karyawan; g) Komunikator yang baik. ${ }^{4}$

Visi-visi terbaik adalah visi yang ideal sekaligus unik. Jika sebuah visi menyampaikan hal yang ideal, visi tersebut mengomunikasikan standar keistimewaan dan pilihan nilai-nilai positif yang jelas. Jika visi tersebut juga unik, hal tersebut mengomunikasikan dan menginspirasikan rasa bangga karena berbeda dari organisasi-organisasi yang lain.5 Secara bersama-sama, visionary leadership menganalisis kemungkinan kemungkinan yang dapat ditempuh, jalan-jalan atau teknik maupun metode serta sumber daya terpilih apa yang dapat digunakan untuk meraih kemajuan di masa depan. ${ }^{6}$ Kepemimpinan visioner kepala sekolah berdasarkan visi misi harus memiliki strategi untuk melaksanakan program-program sekolah yang telah disepakati. Di sinilah pentingnya kepemimpinan visioner kepala sekolah dalam meningkatkan mutu sekolah yang dipimpinnya agar dapat membawa sekolah ke arah kemajuan dan kemandirian.

Kegiatan ekstrakurikuler merupakan kegiatan pembelajaran yang diselenggarakan diluar jam pelajaran yang disesuaikan dengan kebutuhan pengetahuan, pengembangan, bimbingan pembiasaan peserta didik agar memiliki pengetahuan dasar penunjang. ${ }^{7}$ Ekstrakulikuler adalah kegiatan yang dilakukan oleh para siswa sekolah atau universitas, diluar jam belajar kurikulum standar. Mulyono mengemukakan bahwa kegiatan ekstrakulikuler yaitu kegiatan yang dilakukan di luar kelas dan jam pelajaran untuk menumbuhkembangkan potensi peserta didik. ${ }^{8}$ Ekstrakurikuler adalah kegiatan pendidikan di luar mata pelajaran dan pelayanan konseling untuk membantu pengembangan peserta didik sesuai dengan kebutuhan, potensi, bakat, dan minat mereka melalui kegiatan yang secara khusus diselenggarakan oleh pendidik atau tenaga kependidikan yang berkemampuan dan mempunyai kewenangan di sekolah. ${ }^{9}$

Kegiatan ekstrakurikuler diharapkan dapat membantu mengembangkan kreatifitas, bakat dan minat peserta didik untuk menambah wawasan pengetahuan dan pengalaman yang kemungkinan besar tidak mereka dapatkan dari kegiatan kurikuler sehingga dapat dicapai prestasi

${ }^{4}$ Nurul Hidayah, Kepemimpinan Visioner Kepala Sekolah dalam Meningkatkan Mutu Pendidikan, (Yogyakarta: Ar-Ruzz Media, 2016), h. 75.

${ }^{5}$ Ali Akbar Y dan Ria Cahyani, Manajemen Kepemimpinan dan Kolaborasi dalam Dunia yang Kompetitif, (Jakarta: Salemba Empat, 2009), h. 101.

${ }^{6}$ Nurul Hidayah, Kepemimpinan Visioner Kepala Sekolah dalam Meningkatkan Mutu Pendidikan, (Yogyakarta: Ar-Ruzz Media, 2016), h. 81.

${ }^{7}$ Abdul Rachmad Shaleh, Pendidikan Agama dan Pembangunan Watak Bangsa (Jakarta: PT. Grafindanga Persada, 2005), h. 170.

8Mulyono, Manajemen Administrasi \& Organisasi pendidikan. (Jogjakarta: Ar-Ruzz Media, 2014), h. 187.

${ }^{9}$ Rohinah, Membangun Karakter Melalui Kegiatan Ekstrakurikuler, (Yogyakarta: Insan Madani, 2012), h. 75. 


\section{$42 \mid$ Herni}

seoptimal mungkin. Kegiatan ekstrakurikuler yang dimaksud di SMA Negeri 1 Palopo adalah Pramuka, Olahraga (Futsal, Basket, Volly, Bulu tangkis, dan Pencak Silat), dan Paskibra. Akan tetapi, tidak seluruh kegiatan ekstrakurikuler berjalan berbanding lurus dengan tujuan awalnya, yaitu mengarahkan peserta didik untuk mencapai prestasi seoptimal mungkin. Karena pada kenyataannya masih terdapat siswa yang aktif dalam kegiatan ekstrakurikuler di sekolah justru menjadi salah satu faktor yang menjadi penyebab menurunnya prestasi dalam bidang akademik peserta didik. Upaya mewujudkan visi menjadi realita menuntut kapasitas kepemimpinan yang tidak hanya kuat, tetapi juga unggul dalam berbagai bidang di antaranya kegiatan ekstrakuriuler yang dilakukan di sekolah.

Hal ini menuntut kerja keras kepala sekolah untuk tetap menggerakkan serta melakukan pengawasan sumber daya manusia yang dimilikinya dalam membina prestasi siswa di bidang ekstrakurikuler. Atas dasar itu, kepala SMA Negeri 1 Palopo berusaha mewujudkan kepemimpinan visioner dalam rangka mempersiapkan peserta didik yang dapat menghadapi tantangan masa depan termasuk pelaksanaan kegiatan ekstrakurikuler sehingga dapat meningkatkan prestasi dalam bidang akademik maupun non akademik peserta didik.

Fokus penelitian ini menggali lebih dalam mengenai; 1) kegiatan ekstrakurikuler di SMA Negeri 1 Palopo; 2) kepemimpinan visioner kepala sekolah di SMA Negeri 1 Palopo; dan 3) model kepemimpinan visioner dalam mengembangkan kegiatan ekstrakurikuler di SMA Negeri 1 Palopo. Penelitian diharapkan dapat memberikan kontribusi kepada SMA Negeri 1 Palopo mengenai strategi dalam mengembangkan kegiatan ekstrakurikuler melalui implementasi model kepemimpinan visioner.

\section{Metode}

Jenis penelitian ini adalah penelitian kualitatif dengan pendekatan perspektif multidisipliner yang mencakup pendekatan manajerial, psikologis, sosiologis, dan pendekatan religius. Karaktereistik penelitian ini adalah deskriptif kualitatif. Subjek dan objek penelitian ini ialah SMA Negeri 1 Palopo. Teknik pengumpulan data menggunakan observasi dan wawancara. Pengolahan data melalui tahapan editing, coding, dan tabulasi. Selanjutnya, teknik analisis data menggunakan tahapan reduksi data, penyajian data, dan triangulasi, terakhir penarikan kesimpulan.

\section{Kegiatan Ekstrakurikuler di SMA Negeri 1 Palopo}

Kegiatan ekstrakurikuler di SMA Negeri 1 Palopo dilaksanakan berlandaskan dan berpedoman pada aturan pemerintah yang berlaku seperti UU Nomor 20 tahun 2003 tentang Sistem Pendidikan Nasional dan Peraturan Pemerintah Pendidikan dan Kebudayaan Nomor 62 Tahun 2014 tentang 
Kegiatan Ekstrakurikuler pada Pendidikan Dasar dan Menengah. ${ }^{10}$ Terdapat beberapa kegiatan ekstrakurikuler yang ada di SMA Negeri 1 Palopo. 18 jenis kegiatan ekstrakurikuler di sekolah, sehingga para siswa mengikuti kegiatan ekstrakurikuler tersebut sesuai dengan bakat dan minatnya masing-masing.

Tabel 1: Jenis Kegiatan Ekstrakurikuler SMA Negeri 1 Palopo

\begin{tabular}{|c|l|l|l|}
\hline No & Nama Ekstrakurikuler & Waktu Pertemuan & \multicolumn{1}{c|}{ Pembina } \\
\hline 1 & Pramuka & Selasa \& Jum'at & Syamsu Rijal, S.Pd., M.Pd \\
\hline 2 & Pramuka (PI) & Selasa \& Jum'at & Diah Susrini W.,S.Pd \\
\hline 3 & PMR & Kamis \& Sabtu & Nurhikmah Sidang, S.Si \\
\hline 4 & Kir & Senin \& Kamis & Sukmawati Samsu, M.Pd \\
\hline 5 & Sispala & Minggu & Hasrianto Aena \\
\hline 6 & Paskibraka & Rabu \& Jum'at & Suriadi Longsong, M.Pd \\
\hline 7 & Pik Remaja & Senin \& Jum'at & Muhammad Asdar, S.Pd \\
\hline 8 & English Club & Selasa \& Minggu & Sarullah, S.S \\
\hline 9 & SCS & Kamis \& Minggu & Irwandi, S.Pd \\
\hline 10 & Androphy & Jum'at \& Minggu & Eka Darma G., S.Kom \\
\hline 11 & Basket & Rabu \& Jum'at & Saiful Mustafa, S.Or \\
\hline 12 & Drum Band & Selasa \& Sabtu & Alfhaidha, S.Pd \\
\hline 13 & Kran Smansa & Rabu \& Jum'at & Ria Irawati S.Si \\
\hline 14 & Dancety Smansa & Selasa \& Jum'at & A. Ruspika, S.Sos \\
\hline 15 & Rohis & Jum'at & Sudirman, S.Ag.,M.Pd \\
\hline 16 & Einstein Club & Senin \& Jum'at & Saiful, S.Pd \\
\hline 17 & Jurnalistik & Selasa \& Kamis & Karmi Pasanda, S.Pd \\
\hline 18 & Futsal & Selasa \& Jum'at & Takdir Kasim, S.Pd \\
\hline
\end{tabular}

Uraian di atas dipahami bahwa terdapat 18 jenis kegiatan ekstrakurikuler yang ada di SMA Negeri 1 Palopo, namun dari sekian banyak kegiatan ekstrakurikuler tersebut terdapat tiga di antaranya yang menjadi kegiatan esktrakurikuler yang senantiasa membawa nama harum sekolah yaitu pramuka, basket dan paskibraka.

Pelaksanaan kegiatan ekstrakurikuler di SMA Negeri 1 Palopo, pihak sekolah dan juga terutama Pembina kegiatan ekstrakurikuler senantiasa berupaya untuk meningkatkan potensi yang dimiliki oleh siswa secara maksimal dan juga agar nilai-nilai yang terkadung dalam kegiatan tersebut dpat tertanam dalam diri siswa, sehingga pelaksanaan kegiatan ekstrakurikuler berjalan dengan lancar. Oleh karena itu kepemimpinan visioner kepala sekolah senantiasa melakukan upaya agar kegiatan ekstrakurikuler yang dilakukan disekolah tetap senantiasa mendapatkan prestasi dalam setiap pertandingan. Ada beberapa hal yang dilakukan oleh pihak sekolah sehingga kegiatan eskul di sekolah selalu mendapatkan

${ }^{10}$ Departemen Agama RI, Kegiatan Ekstrakurikuler Pendidikan Agama Islam pada Sekolah Umum dan Madrasah, (Direktorat JendralKelembagaan Agama Islam, 2004), h. 11. 
prestasi, di antanya membuat program unggulan dalam hal ini pertandingan basket antar SMA se Sul-Sel, membuka eskul baru yang belum ada di sekolah lain seperti belajar berkhotbah, melibatkan pelatih-pelatih professional pada saat mendekati tanding, serta selalu menanamkan rasa bangga pada diri siswa.

\section{Kepemimpinan Kepala Sekolah yang Visioner dalam Memimpin Pelaksanaan Kegiatan Ekstrakurikuler di SMA Negeri 1 Palopo}

Bentuk kepemimpinan kepala sekolah yang visioner di SMA Negeri 1 Palopo yaitu kepala sekolah yang berpikir lebih jauh ke depan namun tetap berada dalam koridor pendidikan serta merumuskan visi misi sekolah yang jelas ke depannya. Di samping itu untuk menjadi pemimpin yang visioner maka kepala sekolah senantiasa memperlihatkan keteladanan dan kedisiplinan kepada seluruh stake holder sekolah.

Kepala sekolah yang visioner di SMA Negeri 1 Palopo harus dapat mengemban tanggung jawabnya memimpin sekolah dengan berhasil. Kepala sekolah yang visioner harus tahu persis visi dan misi apa yang ingin dicapai dan bagaimana mewujudkan visi dan misi tersebut dalam sebuah amanah yang diemban. Kepala sekolah yang visioner di SMA Negeri 1 Palopo harus memahami betapa pentingnya mengajak semua pihak terkait dalam sekolahnya untuk bersama-sama mewujudkan visi yang telah dirumuskan bersama. Implikasi sifat visioner, kepala sekolah harus memiliki sejumlah kompetensi dan integritas untuk melaksanakan misi guna mewujudkan visi itu, dan selanjutnya kepala sekolah juga harus memiliki sejumlah karakter tertentu yang menunjukkan integritasnya. Bentuk-bentuk kepemimpinan kepala SMA Negeri 1 Palopo yang visioner di antaranya:

\section{Perencaaan visi misi yang jelas}

Kepala sekolah mampu mengimplementasikan visi sekolah dengan baik, berwawasan masa depan, membangun hubungan secara efektif, mampu menggalang seluruh stake holder sekolah dengan baik, berpegang erat pada nilai-nilai spritual yang diyakini, serta berani bertindak dalam mencapai tujuan. Visi Kepemimpinan Visioner di SMA Negeri 1 Palopo mengacu pada kepemimpinan sebagai kemampuan untuk mempengaruhi motivasi atau kompetensi individu-individu lainnya dalam suatu kelompok, budaya musyawarah dalam menentukan arah dan tujuan sekolah, unggul dalam prestasi, terdepan dalam inovasi, maju dalam kreasi serta berwawasan lingkungan. Analisis terhadap bentuk kepemimpinan kepala sekolah di atas menggunakan kepemimpinan kepala sekolah visioner. Hal tersebut dapat dilihat dari caranya memimpin sekolah selama ini dan rencana terhadap program-program sekolah untuk jangka panjang selalu berhasil untuk membuat sekolah semakin berkembang dan diminati masyarakat.

\section{Memiliki inovasi yang tinggi}

Kepala sekolah melakukan beberapa inovasi dalam memimpin kegiatan ekstrakurikuler di sekolah, seperti; membuat program unggulan seperti kegiatan IBB/futsal yang bertaraf, nasional, memberikan motivasi 
dan penghargaan kepada siswa yang berprestasi, mengalokasikan dana RKS dalam pembinaan kegiatan ekstrakurikuler, melakukan latihan secara intensif, melibatkan pelatih-pelatih secara professional, serta melibatkan instansi atau badan terkait dalam hal pelatihan dan pendanaan.

\section{Keteladanan dan kedisiplinan tinggi}

Implementasi keteladanan di kelas SMA Negeri 1 Palopo sudah terlaksana dengan baik yang dilakukan dengan dimulai dari kepala sekolah sendiri dengan memberikan teladan, motivasi maupun pesan moral, kemudian didukung oleh faktor guru yang tegas dan sadar akan pentingnya keteladanan, karena apabila guru berbuat baik maka akan menjadi teladan yang baik juga untuk siswanya sehingga kepemimpinan visioner dapat berjalan dengan baik seperti yang diharapkan. Kepemimpinan kepala sekolah yang visioner dapat dilihat dari keteladan yang dicontohkan oleh kepala sekolah di SMA Negeri 1 Palopo seperti berbicara dengan sopan kepada seluruh stake holder sekolah dalam mengajak dan menghimbau kepada halhal yang lebih baik serta senantiasa memberi sugesti kepada seluruh stake hoder sekolah dalam bentuk menyambut siswa maupun guru dan staff dipintu gerbang sehingga tercipta iklim kekeluargaan di sekolah, dengan cara datang ke sekolah lebih awal, sebelum jam masuk kepala sekolah sudah tiba di sekolah sebelum jam 07.00, dan memberikan teladan memakai seragam sesuai ketentuan dan rapi.

\section{Kepala sekolah menjadi agen perubahan}

Kepemimpinan kepala sekolah yang visioner di SMA Negeri 1 Palopo dapat dilihat dari perubahan yang dilakukan oleh kepala sekolah. Kepala sekolah harus dapat menyadarkan warga sekolah tentang arti pentingnya perubahan kurikulum, memotivasi pelaksanaan perubahan, mampu mengatasi kalau ada kesulitan dalam melaksanakan perubahan, memfasilitasi perubahan, memonitor dan evaluasi pelaksanaan perubahan, mengambil tindakan yang lebih efektif dan efisien untuk melaksanakan perubahan (agen of change). kepala sekolah selalu memikirkan perubahan untuk meningkatkan prestasi SMA Negeri 1 Palopo baik di bidang akademik maupun non-akdemik. Ia menjadi pelopor inovasi rancangan strategis program kerja sekolah terkait implementasi visi. Perubahan dapat dilihat dari peningkatan jumlah siswa, programpembelajaran baru, kerjasama yang semakin ditingkatkan, pendidikan religius, memberdayaan SDM.

Sebagai agen perubahan dalam pelaksanaan kegiatan ekstrakurikuler di sekolah, ada beberapa hal yang saya lakukan di sekolah yaitu, mengarahkan siswa untuk melakukan perubahan-perubahan strategi dalam latihan agar lebih maju dalam pencapaian hasil, memberikan semangat kepada siswa dalam pencapaian target juara pada tingkat nasional, serta menanamkan rasa bangga kepada siswa atas prestasi yang dimiliki. Evaluasi perubahan oleh kepala sekolah dalam pengambilan keputusan. yang digunakan oleh Kepala Sekolah SMA Negeri 1 Palopo, perubahan oleh kepala sekolah, Keberhasilan pendidikan sesungguhnya akan terjadi bila ada interaksi antara tenaga pendidik dengan peserta didik. Guru sebagai tenaga pendidik merupakan pemimpin pendidikan, dia amat menentukan dalam 
proses pembelajaran di kelas, dan peran kepemimpinan tersebut akan tercermin dari bagaimana guru melaksanakan peran dan tugasnya.

\section{Model Kepemimpinan Visioner Kepala Sekolah dalam Mengembangkan Kegiatan Ekstrakurikuler di SMA Negeri 1 Palopo}

Model kepemimpinan visioner kepala sekolah dalam mengembangkan kegitan ekstrakurikuler di SMA Negeri 1 Palopo antara lain:

\section{Perumusan visi}

Perumusan visi kepala sekolah senantiasa disesuaikan dengan kultur sekolah, ekonomi, sosial, kebutuhan siswa dan demografis. Di samping itu, kepala sekolah juga selalu memberikan support dan motivasi kepada para pelatih dan siswa untuk selalu bersemangat dalam mengikuti latihan. Kepala sekolah dalam merumuskan visi sekolah kepala sekolah yang senantiasa disesuaikan dengan kultur sekolah, ekonomi, sosial, kebutuhan siswa dan demografis. Hal ini tentunya dilaksanakan secara bersama dalam mengembangkan komitmen, partisipasi, kerjasama, dan dukungan dari pihak semua pihak yang terlibat dalam perumusan visi sehingga setiap perubahan sekolah yang dilakukan yang dapat terus berjalan, menginternal dalam diri warga sekolah dan juga melembaga dalam kehidupan sehari-hari di sekolah.

\section{Transformasi visi}

Transformasi visi yang dilakukan oleh kepala SMA Negeri 1 Palopo secara garis besar dilakukan melalui dua cara, yakni; 1) secara langsung, dilakukan dengan menyampaikan secara langsung kepada seluruh komunitas sekolah melalui forum formal. Bapak Muhammad Arsyad, S.Pd selaku kepala sekolah selalu berupaya untuk mentransformasikan visi sekolah dalam setiap kesempatan rapat. Adapun forum rapat tersebut di antaranya rapat kerja di awal tahun pembelajaran, rapat evaluasi setiap 6 bulan; 2) tidak langsung, Transformasi visi secara tidak langsung dilakukan pada suatu kegiatan tertentu, menggunakan media-media tertentu yang dapat mendukung transformasi visi. Transformasi visi secara tidak langsung yang dilakukan kepala sekolah di antaranya dengan membuat spanduk besar yang direntangkan di tembok depan gerbang masuk sekolah. Pemasangan spanduk ini juga menjadi sarana transformasi yang paling efektif antara sekolah dengan pihak luar. Proses transformasi visi ini bertujuan untuk menyatukan persepsi seluruh komunitas sekolah agar selaras dengan citacita sekolah yang ingin dicapai sehingga meningkatnya mutu SMA Negeri 1 Palopo khususnya yang menyangkut kegiatan ekstrakurikuler.

\section{Implementasi visi}

Implementasi visi kepala sekolah dalam mengembangkan kegiatan ekstrakurikuler di SMA Negeri 1 Palopo yaitu pelaksanaan kegiatan ekstrakurikuler di sekolah dilaksanakan berdasarkan rencana strategis program kerja hasil pemetaan bakat dan minat siswa terhadap kegiatan ekstrakurikuler yang ada di sekolah. Di samping itu implementasinya dituangkan dalam bentuk: guru pembimbing membentuk susunan pengurus, membuat jadwal pelaksanan, melaksanakan kegiatan dan pemantuan serta 
memberikan motivasi agar pelaksanaanya berlangsung sesuai dengan perencanaan awal sehingga berakhir pada pencapaian prestasi yang baik. Pengimplementasian visi di SMA Negeri 1 Palopo berpedoman pada rencana strategis program kerja. Munculnya rencana strategis program kerja didasarkan pada analisis dalam standar nasional pendidikan yang meliputi standar isi, standar proses, standar pengelolaan, standar kompetensi lulusan, standar sarana dan prasarana, standar pembiyayaan, standar tenaga pendidik dan kependidikan, standar evaluasi/penilaian.

Secara garis besar peran kepala sekolah dalam mengimplementasikan visi untuk meningkatkan mutu SMA Negeri 1 Palopo khususnya dalam kegiatan ekstrakurikuler yaitu: 1) Memberikan contoh keteladanan disiplin kerja yang baik kepada guru, staf dan karyawan sehingga merasa termotivasi untuk selalu disiplin; 2) Melakukan koordinasi, komunikasi, dan konsultasi dengan para stakeholders terkait kegiatan ekstrakurikuler; 3) Sebagai evaluator dan motivator terhadap kinerja para guru, staf dan karyawan dalam rangka implementasi visi; 4) Mengadakan training, dan diklat kepada para guru guna meningkatkan kualitas/kompetensi guru.

\section{Melengkapi sarana dan prasarana kegiatan ekstrakurikuler}

Langkah-langkah kepala sekolah dalam mengembangkan kegitan ekstrakurikuler di SMA Negeri 1 Palopo yaitu pihak sekolah senantiasa memprogramkan sarana dan prasarana yang dibutuhkan pada kegiatan tersebut dalam penyusunan RAKS oleh setiap kegiatan ekstrakurikuler di sekolah. Sarana yang dimaksud adalah: 1) Sarana ekstrakurikuler pramuka seperti tenda, tongkat, tali badai serta kebutuhan lain; 2) Sarana ekstrakurikuler paskibraka sepetri bendera latihan, sepatu latihan dan lapangan yang memadai; dan 3) Sarana ekstrakurikuler basket seperti bola basket dan lapangan khusus baskert. Dan yang tidak kalah pentingnya dari ketiga esktrakurikuler tersebut adalah Pembina atau pelatih yang professional dalam bidangnya masing-masing.

Agar kegiatan ekstrakurikuler di sekolah senantiasa berjalan dengan lancar maka kepala sekolah selalu mengalokasikan dana untuk memperbaharui sarana dan prasarana kebutuhan eskul yang sudah tidak baik, dan selalu melibatkan instansi terkait apabila diperlukan seperti, Dinas Pemuda dan Olahraga, Dinas Pariwisata di bidang Seni, Koni, dan juga pemerintah setempat.

\section{Model pembelajaran dan pelatihan ekstrakurikuler SMA Negeri 1 Palopo}

Adapun model pembelajaran dan pelatihan ekstrakurikuler SMA Negeri 1 Palopo antara lain: 1) Memotivasi: pada awal melakukan kegiatan ekstrakurikuler atau disaat perekrutan anggota ekstrakurikuler kepala sekolah memberi motifasi kepada siswa dengan menjelaskan tujuan dan manfaat kegiatan ekstrakurikuler; 2) Menyenangkan: kegiatan ekstrakurikuler dilaksanakan dengan suasana menggembirakan siswa, seperti: siswa dibebaskan dalam menentukan pilihan ekstrakurikuler sesuai bakat dan minatnya, dan pembina ekstrakurikuler diharapkan memberi latihan-latihan kepada siswa dengan metode yang menyenangkan; 3) Mensupport: kepala sekolah selalu mensupport setiap hasil yang diperoleh 
48 | Herni

siswa dalam kegiatan ekstrakurikuler di SMA Negeri 1 Palopo dan mendukung sepenuhya peningkatan ekstrakurikuler selama itu masih sesuai dengan aturan tata tertib sekolah; 4) Memberdayakan: kepala sekolah memberdayakan seluruh stakeholder sekolah dimasing-masing bidang ekstrakurikuler sesuai dengan keahliannya; dan 5) Mengimplementasikan: kepala sekolah selalu melaksanakan seluruh kegiatan yang telah disepakati baik itu berupa jadwal latihan, pertandingan atau lomba baik di dalam sekolah maupun di luar sekolah.

\section{Kesimpulan}

Kepemimpinan kepala sekolah yang visioner dalam memimpin pelaksanaan kegiatan ekstrakurikuler di SMA Negeri 1 Palopo dapat dilihat dari segi perencanaan visi misi yang jelas, memiliki inovasi yang tinggi, keteladanan dan kedisiplinan yang tinggi, serta kepala sekolah menjadi agen perubahan. Model kepemimpinan visioner kepala sekolah dalam mengembangkan kegitan ekstrakurikuler di SMA Negeri 1 Palopo terdiri dari perumusan visi, transformasi visi, implementasi visi, serta melengkapi sarana dan prasarana. Di samping itu kepala sekolah juga menerapkan konsep $5 \mathrm{M}$ yaitu memotivasi, menyenangkan, mensupport, memberdayakan, dan mengimplementasikan.

\section{Daftar Pustaka}

Abdul Rachmad Shaleh. 2005. Pendidikan Agama dan Pembangunan Watak Bangsa, Jakarta: PT. Grafindanga Persada.

Achmad Sanusi dan Sobry Sutikno. 2009. Kepemimpinan Sekarang dan Masa Depan, Bandung: Prospect.

Ali Akbar Y dan Ria Cahyani. 2009. Manajemen Kepemimpinan dan Kolaborasi dalam Dunia yang Kompetitif, Jakarta: Salemba Empat.

Departemen Agama RI. 2004. Kegiatan Ekstrakurikuler Pendidikan Agama Islam pada Sekolah Umum dan Madrasah, (Direktorat JendralKelembagaan Agama Islam.

George A, Stainer. 2006. Strategic Planning, New York: The Free Press.

Mulyono. 2014. Manajemen Administrasi \& Organisasi pendidikan. Jogjakarta: Ar-Ruzz Media

Nurul Hidayah. 2016. Kepemimpinan Visioner Kepala Sekolah dalam Meningkatkan Mutu Pendidikan, Yogyakarta: Ar-Ruzz Media.

Nurul Hidayah. 2016. Kepemimpinan Visioner Kepala Sekolah dalam Meningkatkan Mutu Pendidikan, Yogyakarta: Ar-Ruzz Media.

Rohinah. 2012. Membangun Karakter Melalui Kegiatan Ekstrakurikuler, Yogyakarta: Insan Madani.

Tim Dosen Administrasi Pendidikan Universitas Pendidikan Indonesia. 2009. Manajemen Pendidikan, Bandung: Alfabeta. 